\title{
Professionalization and Public Service Career in Mexico-Toward a Policy of Urgent State
}

\author{
Roberto Moreno Espinosa \\ Autonomous University of the State of Mexico, Toluca, Mexico \\ Oscar Mauricio Covarrubias Moreno \\ UNAM, Mexico City, Mexico
}

\begin{abstract}
At present, the problems facing the process of professionalization and the introduction of professional service career at the three levels of government in Mexico, in order to generalize the merit principle as the basis for entry into the civil service, continue coating a large complexity in addition to resistance from state and municipal governments. In this, it is argued that only through promoting a state policy on the matter involving stakeholders: federal, state, and municipal governments, institutions forming higher education cadres for politics and public administration at the institutions of national and state administration, specialists and civil society at the end, is how it can shape a policy that will lead to greater professionalism and performance of cadres to serve the government, given the challenges facing the country in the 21 st century.
\end{abstract}

Keywords: professionalism, public service, government policy

Addressing issues about civil professionalization and career service in Mexico, continue to be topics of relevance, incompleteness, and source of expectations and frustrations, linked to the vicissitudes of changes every six years in the case of the federal government and the federal entities, in little more than 2,440 triennial municipalities in the country. This phenomenon resembles the fabric of Penelope, which is advanced in some years, was thrown overboard and start again with consequent losses in the capacities of government, public administration, and management, as well as the social cost that this represents and even in corruption indices that characterize the Mexican state not eventually be eliminated or at least alleviated. It is understood, to some extent, as a result of the political change that characterizes the country in the three tiers of government, however, even in the case of the same political party leading the country's destiny from the presidential year, every six years' settings do not wait regardless of job profiles and performance, which ends up being a practice that is identified by a characteristic of endemic of the political regime.

Corresponding author: Roberto Moreno Espinosa, Ph.D. in public administration, FCPyS-UNAM, career professor, Autonomous University of the State of Mexico, President of the International Academy of Political and Administrative Sciences and Future Studies, C.A.; research fields: theory of public administration, professionalization of public service, management and administration of local governments. E-mail: roberto.moreno@iapas.mx.

Oscar Mauricio Covarrubias Moreno, Ph.D. in political and social sciences, UNAM, secretary general and researcher, University of Business and Pedagogic Development, Vice President of the International Academy of Political and Administrative Sciences and Future Studies, C.A.; research fields: government coordination and transversality, educational management, and public policy. E-mail: mauri@unam.mx. 
To explain the phenomenon briefly described, it is necessary to scrutinize the past, in order to highlight the foundation on which the political regime that emerged from the Mexican Revolution rises, since a little more than a decade of the third federal constitution legislate of Mexico Party antecedent of the Institutional Revolutionary Party (Partido Revolucionario Institucional, PRI) is founded, then the National Revolutionary Party (Partido Nacional Revolucionario, PNR), which marked a milestone in stabilizing the turbulent situation that the country went through in the second decade of the 20th century, takeoff of Mexican Presidentialism, as in the strengthening of the political class and the integrated main groups, whose political-administrative control lasted until well into the century quoted, which ran counter to the professionalization and conformation models of professional service career, since politicians favored the system of political spoils or patronage well above the merit principle, which resulted in a patrimonial administration handled and manipulated with high discretion, which clearly was antithetical to the high professionalism of tables serving government.

In the rest of the century, only incremental steps that favored the professionalization of cadres in the service of the federal public administration so focused in both the central public administration and the parastatal, notably in the foreign service in the armed forces took and in some areas of hacienda administration in the first, the second several decentralized agencies were favored as the authors will point out below, and more recently, the so-called independent agencies, have greater professionalism in the tables that comprise them, such as National Human Rights Commission (Comisión Nacional de los Derechos Humanos, CNDH), the Bank of Mexico (Banco de México, BANXICO), the Federal Electoral Institute (Instituto Federal Electoral, IFE), and the National Institute of Statistics and Geography (Instituto Nacional de Estadistica y Geografia, INEGI).

In this development, a brief analysis of the perspective that currently presents the professionalization of public service in Mexico, then raise to broadly outline the need for a national policy on professional status and public service career to the challenges, currently facing the Mexican Government finally developing a final thought and the authors include the sources of information used.

\section{The Professionalism and Service Career in Mexico in Historical Perspective}

Professionalization and the career service in Mexico have historically been linked to changes and political uncertainties, as well as the particularities and the prevailing political regime path. During the genesis, development and consolidation of the regime that emerged from the Mexican Revolution (1910-1917) has been one of the longest running at a global level, civil service professionalization and factors have not accounted for or priority areas in the political agenda-administrative, although they were not entirely ignored as discussed below.

It can be said that these factors became second or third place in inverse proportion to the consolidation of the political system right, which means that to the extent that it took hold, considered the relevance of implementing a model civil or professional career service within the scope of the federal government, at the state level of government, administration and management, or local government, it could transform more of a hindrance than an achievement or goal priority to the interests of the political class.

Thus, the merit system as a resource or model for recruiting and professionalizing the administrative cadres to serve the state and fundamental pillars for the purposes of this screened by the political class and the political party that eventually became the hegemonic Party of the Mexican Revolution (Partido de la Revolución Mexicana, PRM), ceased to be a central goal, as conditions required to give way to political spoils system, better known and identified with cronyism and nepotism, where nepotism and cronyism became the 
rule rather than exception. Other problems were elevated in priority such as the country's reconstruction, political stabilization, or pacification, given the same multiplicity of groups, factions, parties, and other political forces of all sizes prevailing at the time.

However, it is very significant that in the first years of the regime of the revolution, it has been legislated on civil service, as demonstrated by the initiative of President Abelardo L. Rodríguez, the third of the presidents better known as "the cactus", Emilio Portes Gil and Pascual Ortiz Rubio before him - who managed to stay in office over six years, space-time described as "the maximato or pelelismo" (1929-1934).

It is notable that one political group had in mind and plans the need to promote civil service, perhaps as a device for projecting system and strengthen institutions and protect from attempts to return to warlordism, crass attempt, since it is lived the period cited maximato - the power behind the throne, the initiative of the Civil Service Law Career transformed not only unheeded, but the starting point of a simulation exercise which lasted until the end of century, since the modernization Program of the Federal Public Administration (The Programa para la Modernización de la Administración Pública, PROMAP) launched during the administration headed by Ernesto Zedillo, it has as one of its essential points - the establishment of a civil service career, which eventually became an exercise, more simulation chronic announced long lasting. In the particular case, it is worth remembering the struggle or controversy that was evident between the Ministry of Finance and the then Ministry of Comptrollership and Administrative Development which sought to launch and control the civil service model, which resulted long to give the design and implementation of a model of civil service and lay a more solid foundation for real and high professionalization of cadres to serve the federal government.

Retaking the initiative of President Rodriguez and its ineffectiveness, is evidence that the political regime became aware promptly of strength rising, which meant that a system of materialized merit in a model of civil service would lead to delimiting the cake out gradually, and to that extent, limiting the possibilities of placing the friend, the family member, and regime stalwarts to the relevant posts and positions beyond their training and eventual performance.

A Model of Career Civil Service soon became dysfunctional in the regime and on the other side of the coin, a disgrace to the country, since it was not possible to lay the foundation to build a highly professional public service and if this scenario occurred in the area of federal government, what happened in the governments and administrations of the federal states was only diminished, deformed, and report of the federal model replica, given the increase in the strength of Mexican Presidentialism, do not forget that governments and state government were an extension of the central government and to which he was not allowed to shine, add to, or try to increase their autonomy and, of course, think of originality as to introduce a merit system or public service career in their bodies.

As relates to municipal ordinance regarding the promotion of the merit system and outlining a professionalization of these pictures, it was all but impossible, since the situation that enveloped him was synonymous with neglect, desolation, ninguneo, and absolute subordinated genuine disaster area; remember that since the beginning of independent Mexico until the end of the 20th century, specifically to 1999, the town was not government but only administration, it was not granted the status of a high standard and dignity, although it was considered as the basis for the territorial division as well as domestic political and administrative organization of the states, was iteratively denied the character of government, as well as greater powers and resources, thus lost, perhaps forever that Mexico aspired to be a decentralized country with a genuine federalism as settled since the Act of Federation in 1824. 
With the neglect and abandonment of the town, historic opportunities not only to achieve a more comprehensive development and have laid a firmer foundation to limit human bloodletting that has meant emigration, primarily to the American Union were lost, and have managed to deploy local potential.

In this scenario, professionalization of cadres in the service of the city administration became a diffuse object and short range. In sum, the municipal public administration fell into a scenario where improvisation of merit system as a mechanism for the recruitment and development of staff at your service almost was discarded; in return, the loot system laid its real, while at the time still abounds at home in most of the municipalities, except those where local legislation on public service professionalism and begins to have some effect as in the case of Yucatán and Zacatecas, to cite two examples.

The simulation exercise to which the authors refer came to an end in the area of federal civil service in April 2003, with the promulgation and publication in the Official Gazette of the Law on Public Service Career of the Federal Public Administration, raising more than a few expectations of progress to a real professionalization and establishment of the merit system in the form of a model of Public Service Race, however, it seems that the simulation exercise just changed clothes since the model has been short-sighted, the most unfortunate thing is that in the last four years of the six-year period headed by Felipe Calderon Hinojosa, the mechanism of recruitment of cadres predominantly verified through the application of Article 34 which gives rise to senior officers to recruit cadres at their convenience, which means neither more nor less than a system of legalized plunder and may eventually be worse than the old system of open loot. Of course, we must also admit that it has incorporated the federal public administration boxes highly.

It is also appropriate to make a brief allusion to those experiences where professionalism and models of civil service have driven that represent the other side of the coin: these experiences are, in essence, the following: (1) foreign service; (2) teaching career, currently being reformed; (3) Vocational Training Institute of the Attorney General of the Federal District: recruitment and selection; (4) Training Institute of the Attorney General's Office; (5) professionalism in the provision of electoral services by the Executive Director of the Professional electoral service of the Federal Electoral Institute (Instituto Federal Electoral, IFE), now the National Electoral Institute (Instituto Nacional Electoral, INE); (6) hydraulic system specialists at the National Water Commission; (7) professionalization of public servants in the agrarian; (8) Integral System Professionalization: The experience of the INEGI; and (9) Service Tax Administration (SAT).

In sum, the balance left us a brief retrospective analysis about the professionalism and the public and civil service career in Mexico, allows us to glimpse the need for professionalism and high performance public administration government and has been a constant need, if anything, intensified in some areas, items, or functions, or as a result of various reforms that have been printed for public administration. With regard to the civil service, evidence of multiple attempts to establish it, however, fundamentally political reasons and preservation needs of the corporate client regime eventually stop.

The professionalization of the public service and its members have been an ongoing need, not necessarily attended, today is an urgent to address and meet the multiple demands of an increasingly demanding society and participatory requirement. Similarly, to the extent that the intersections and encounters between the state and society are larger, they tend to modern governance in which the government and public authorities have a greater number of partners and therefore require increasing their capacities of both government and administration and management, which emphasizes the need to increase levels of professionalism of public servants. 


\section{Current Perspective of Professionalization in Mexico}

As the arrival of the 21 st century, Mexico on professionalism and career public service was low key and alternating conditions imposed that would transit presaged a scene clean slate; it was expected that if traditionally every presidential change many pictures of the so-called middle managers and above were changed with the arrival of the National Action Party (Partido Acción Nacional, PAN) to the federal government, the removal would be even greater, as indeed happened, so he forced the departure of many high performance frames that obviously were not protected by an outline or model of professional career service. At the time, he went to the process of recruiting firms that will track potential talent for adding to the federal public service of the new regime, from the level of secretary of state to heads of departments, as well as recruit cadres from the private sector and the business world for the same purpose. It was well-shaped a new kind of public service where the definition of a mixed model that incorporated many criteria, styles, and ways to manage the private sector in the public sphere is perceived; a sui generis management model was consistent with the objectives of the new group and political class in power.

A strategy of professionalisation of pictures of the federal public administration was mainly attended by private institutions of higher education for development and implementation of training programs and update. With regard to civil or professional career service, quickly they held forums, debates, and proposals for the eventual implementation, which most strongly claimed was led by Senators Carlos Rojas and César Jáuregui, the proposal took the form of initiating a law which was discussed and approved by the chamber of origin, in this case, the senate which since 2002 sent to the House of Review, where was shelved in the first instance; however, the arrival of Deputy National Action Armando Salinas coordination of the Commission of Government and Public Security of the LVIII Legislature of the Chamber of Deputies, fundamentally promoted the adoption of the proposed law.

Notably, in March 2003, the Mexican Network of Professional Service organized a thorough discussion where involving national and international experts and representatives of the various parliamentary representation in the House of Representatives regarding the professionalization of public service in Mexico, where it was discussed and debated thoroughly regarding the urgent need to promote the professionalization of the civil service, in keeping with the needs and challenges facing the country, facing the start of the century, the results were very satisfactory, since that the measure of the Professional Civil Service of the Federal Public Administration gained unusual strength and was finally passed in the House of Representatives and signed by the federal government in April 2003, certainly raised before and after a series of questions and called attention around issues related to unprecedented scenario as well, David Arellano Gault said:

Transforming administrative culture accustomed to a high level of discretion of elected and appointed in the administration of human resources policy, is certainly one of the main obstacles. This adds to the fact that the separation of administrative and political career is still under construction... Finally, Arellano adds but not least important, Mexican-regulated system based on mistrust in simulation as a way of life in the enormous capacity to seek to modify the rules for their own benefit, make up the mosaic of challenges that they face. (Arellano Gault, 2008)

So, we proceeded to design a new institutional framework for civil service and it still has broad questions. It is essential that state and civil society to keep attention away from what is at stake and model professional career service force, which must be consistent with our needs and expectations, it is noteworthy that of vitalizing the model, possesses all institutions that can and should support this national project: schools, unions, 
experts, networks, institutions of higher education excellence, and in addition to the basic laws and regulations, including the current realities.

At the state and municipal level, the National Governors' Conference (Conferencia Nacional de Gobernadores, CONAGO) has discussed the need and relevance in developing and fostering the professionalization of cadres to their service, and the municipalities in several meetings, however, the task at both levels of government is still arduous, it is commendable that has been already defined strategies and programs to achieve such professionalism, which is still in process, it is essential to take appropriate measures to secure a national level such purposes.

\section{The Professionalization of Public Service in Mexico: A Matter of National Interest}

The transformations that characterize the country's political, economic, and social spheres during the 21 st century are of high caliber. In the first case, the political change was consolidated at the three levels of government in the Mexican federal government, which seemed unlikely so that started at the municipal level since the early $80 \mathrm{~s}$ and late in the same state, finally at the end of the century takes place in the federal government, thus passing through new paths that conform, Bertha Lerner stands as a complex governance, in contrast to the authoritarian governance that preceded it, we find ourselves in an environment where the concept of divided government, characteristic of a society in which prevails categorically concrete reality in a party system in full swing.

In the economic sphere, the most intense phase where multiple free trade agreements were negotiated, to North, Central, South America, the European Union (EU), the Middle and the Far East, and had been overcome and that shows the transition from the which was a protectionist to a clear opening to the outside economy. In the 21 st century, what mattered was a proper cope in highly competitive and competitive environment of globalization advances and globalization, an issue raised by a number of challenges in itself complex, as well as opportunities, however, the newcomer new political regime led by the PAN, it was not easy to adapt and deploy the potentials and capabilities required to navigate the turbulent waters evidencing trade liberalization, speculative movements, uneven and combined competence of international scenarios, question which did not escape the subnational and local governments.

In the social sphere, differentiation, pluralization, mobilization, and new role of civil society in contrast to the prevailing at the time of the authoritarian, corporate, and client regime that was promoted in the old regime, starting to look that far nonconformist society anesthetized and subjected no doubt it was arriving at new times.

In short, the scene of the century corresponded to a more complex society, demanding, willing to move to unmet basic needs, however, the ravages of trade liberalization, the economic model followed, still causing a highly unequal income distribution, thereby generating large sections and belts of poverty and extreme poverty, to the extent that more than half of the population of the country was, and still in such a situation.

In the above stated environment, Mexico is required to clearly increase the capacity of government, administration, and management, which was not easy, the arrival of a new political force represented a series of adjustments that had a high social cost was so the need to strengthen the professionalism of the civil service emerged as one of the factors to address, as the formulation and implementation of a model of professional service career. Thus, both factors are factors to date national interest, since it requires leaving behind improvisation, amateurism, cronyism, and nepotism and reach once and for all to a system based on merit allows and ensures the implementation of programs of high economic, social, and political impact. Notably, the 
professionalization of the public service as a concurrent subject between the orders of government, and we have noted that demand otherwise promote a state policy in the field.

(1) The concurrence or coincidence that occurs in practice, to have the federal and state governments and collective or common areas by the fact that they develop actions that deal with the same population living in the same territory interests. This is particularly relevant in the face of a marked trend toward federalism in the current expansion or multiplication of areas of common decision, as well as the establishment of local intergovernmental relations;

(2) There is a relationship of coordination in the field of democratic planning, which is essential to implement to encourage the promotion and strengthening of the professionalization of cadres to serve the public administrations of the three levels of government and go outlining the establishment of the merit system through the development of models of flexible professional service career;

(3) This is explained largely by the impact of problems or public affairs incessantly spilling existing political and administrative jurisdictions, both in the sectoral intergovernmental plane. These are issues of cross-cutting nature, in the sense that no limits or stop at no barrier, with or reciprocally interrelated causes and certain effects. We have certainly faced an increase in the number of problems that states can only solve cooperatively;

(4) A boost to the development of professional models and professional service career based on this type of strategy, where schemes can profile including the exchange of frames between levels of government at the same level may be feasible according to the needs of stakeholders, a common practice in several countries.

\section{Toward a State Policy in the Field of Public Service Professionalism and Career}

State policies were taken on a particular significance in various public issues whose complexity, relevance, scope, and significance are of importance to national coverage, demanding of resources, policy formulation, and efficient implementation that allowed no delay, lest iteratively require attention and involve higher costs and large gaps that are difficult to overcome; correspond to a genuine awareness of not only its importance, but also of the opportunity with which must be addressed, and issues such as the promotion of science, technology, and innovation; the quality of education at all levels and modalities, and of course the development of the high professionalism of the pictures in the service of the three branches of government.

We conducted a set of pointing around the need to promote a state policy of national scope that takes as its central theme, the professionalization of cadres to serve the public administrations of the three levels of government. It is far-reaching actions that correspond to the both government and society deal set, taking into account the aims to meet complex and cross-cutting issues that affect everyone. It corresponds by the definition highly consensual public policies that exceed periods of government at the federal and state and municipal levels.

\section{Challenges for Mexico's Public Administration}

In a span of 20 months, it conducted 11 structural reforms, all transversally cross the whole national life in multiple terrains and areas, and areas namely: (1) work; (2) finance; (3) fiscal; (4) in antitrust; (5) education; (6) in telecommunications; (7) political-electoral; (8) New Amparo Law; (9) National Code of Criminal Procedure; (10) transparency; and (11) energy. To enable such reform package, the Mexican political regime managed signature called Pact for Mexico by the three political parties which are more representative: the PRI, the PAN, 
and the Party of the Democratic Revolution (Partido de la Revolución Democrática, PRD), then the law appropriate by the two chambers that make up the congress (senators and representatives), which came in the midst of turmoil, questions, and demonstrations.

In this regard, it is noteworthy that the legislative-regulatory part is completed, taking into account that have been enacted by the federal executive and published in the Official Gazette; likewise has already led to the creation of a set of organisms essential for the phase of implementation of those reforms among which there are to tell the new National Institute for Educational Evaluation, the Federal Institute for Telecommunications, the new INE replacing the previous IFE, the new Federal Institute for Access to Information and Data Protection, which already has constitutional autonomy, as well as other existing and the National Commission of Hydrocarbons and Energy Regulatory Commission, among others.

The implementation phase of all 11 reforms raises several questions and points once again highlighted if you have pictures with the appropriate profiles to implement efficiently these reforms or will settle for mediocre scope and that the potentialities which apparently offer once again remain in good intentions and essentially lead to frustrations, disappointments besides deepening distrust in public institutions.

\section{Final Thoughts}

The political change in the federal government for the second time in this century in Mexico meant the return of the party that held power for more than 70 years last century, newly installed again in the Pines, negotiated and managed the firm's already alluded Mexico Pact catalyzed promoting structural reform legislation in 10 who join the Labour promoted during the six-year transition. In most of these, it is passed and to the implementation phase and raises several questions regarding the management model that will prevail, and managerial character or a more inclusive than approach one more participatory governance that accommodates the agreement signed by Mexico concerning the so-called "open government"; the question also arises in that if the service career of the federal public service as a device needed to have high performance boxes to ensure greater success in implementing structural reforms legislated cluster will be strengthened.

It notes that the current regime is heir, and practicing a policy of plunder not yet banished and covering the three levels of government.

\section{References}

Arellano Gault, D. (2008). The implementation of a civil service meritocracy: A technical issue? The case of Mexico. In F. Longo and C. Ramió (Eds.), Professionalization public employment in Latin America. Barcelona: CIDOB Fundation.

Arellano Rios, A. (2011). The government into the Mexican municipality: Reflections on institutional design. Region and Society, 23(52), 59-90.

Brugué, Q., \& Subirats, J. (1996). Readings of governance. Spain: Ministry of Public Administration, INAP.

Covarrubias Oscar Mauricio Moreno. (2008). Mainstreaming and coordination of state policies on federalism. Discussion Paper Series, No. 12 - 20th Contest of CLAD on State Reform and Modernization of Public Administration. How to face the challenges of mainstreaming and intersectoral in public administration? Essays Winners 2007. Retrieved from http://www.clad.org.ve/portal/publicaciones-del-clad/series/serie-documentos-debate-1

Echebarría Koldo. (2003). "The vision of the IDB" on professionalization of public service in Mexico: Towards innovation and democracy. Universidad Iberoamericana (The Ibero-American University), Mexico,

Gasca Pliego, E., \& Olvera Garcia, J. C. (2010). The municipality in the global context. Challenges for setting a vision of integral development, from the municipal level. Proceedings from the 1st International Congress Government, Management and Professionalism Locally to the Great Challenges of Our Time. Ayapango, Mexico. 
Ibarra Salazar, J., González, H., \& Sotres Cervantes, L. (2013). Political aspects of financial dependence on Mexican municipalities. Mexican Journal of Political and Social Science, 58(217), 139-170.

Lerner, B., Uvalle, R., \& Moreno, R. (2012). Governance and governance at the beginning of the XXI century and contemporary reflections on Mexico. IIS-UNAM-IAPEM, Mexico.

Mayntz, R. (2002, October). Nation states and global governance. CLAD Magazine of Reform and Democracy, 24.

Méndez, J. L. (2003). The professionalization of the Mexican state: Waiting for Godot again. Professionalization of public service in Mexico: Towards innovation and democracy. Mexico: Universidad Iberoamericana (The Ibero-American University).

Merino Huerta, M. (1992). Outside the centre. Reflections on Mexican political centralism. Mexico: Veracruzana University.

Moreno Espinosa, R. (1995). The territorial administration in Mexico, historical background. Mexico: IAPEM-UAEM.

Moreno Espinosa, R. (2003). Political regime and decentralization of public administration in Mexico from 1977 to 2002. Proceedings from the Sixth Congress AECPA, Governing in Europe, Governing Europe. September 18-20, Barcelona.

Moreno Espinosa, R. (2005). The implementation of professional service career in Mexico: An analysis from the neoinstitucionalismo. Proceedings form the 10th International Congress of CLAD on State Reform and Public Administration. October 18-21, Santiago de Chile.

Moreno Espinosa, R. (2007). Contradictions, opportunities and challenges of local governments in Mexico for the twenty-first century. Proceedings from the 12th International Congress of CLAD. October 30 to November 2, Santo Domingo, Dominican Republic.

Moreno Espinosa, R. (2013). Challenges of local governments in an environment of advanced governance: The Mexican case. Proceedings from the 18th International Congress of CLAD. October 29 to November 1, Montevideo, Uruguay.

Puón Martínez, R. (2003). Professional and managerial career service for what? Notes for its development and institutionalization in Mexico. Proceedings from the 7th Congress of CLAD on State Reform and Public Administration. October, Panama.

Rodriguez Castillo, L. (2012). Municipality, innovation and development in Latin America. Towns and Digital Frontiers Magazine, 7(13), 2-7.

Salinas Sandoval, M. D. C. (2001). Municipalities in the formation of the State of Mexico, 1824-1846. Mexico State College, Mexico.

Sanchez Montiel, J. C. (2005). Bibliographic essay on the municipality. Studies in Modern and Contemporary History of Mexico, 29, 175-186.

Sánchez Torres, C. A., \& Corner, E. C. (2004). Digital municipality and e-government. Universitas, 107, 813-847.

Yanome Yesaki, M. (2005). The judicial power of the municipalities in Mexico. Mexican Bulletin of Comparative Law.

Zúñiga Cardenas, J. O. (1992). The Mexican municipality in the XXI Century: A histographic approach. UJAT, Mexico. 